\title{
REVIEW
}

\section{Uncertain status of the northern bottlenose whale Hyperoodon ampullatus: population fragmentation, legacy of whaling and current threats}

\author{
Hal Whitehead ${ }^{1, *}$, Sascha K. Hooker ${ }^{2}$ \\ ${ }^{1}$ Department of Biology, Dalhousie University, Halifax, Nova Scotia, B3H 4J1, Canada \\ ${ }^{2}$ Sea Mammal Research Unit, Scottish Oceans Institute, University of St Andrews, St Andrews KY16 8LB, UK
}

\begin{abstract}
The northern bottlenose whale Hyperoodon ampullatus is the best-known beaked whale species, but its conservation status remains very uncertain. A medium-sized cetacean that lives in the deeper waters of the northern North Atlantic, it is remarkable for its deep dives and inquisitiveness towards ships. There seem to have been of the order of 100000 whales prior to $40 \mathrm{yr}$ of intense whaling beginning in the $1880 \mathrm{~s}$, and this population was undoubtedly heavily reduced by 1920. The effects of a second phase of whaling between 1937 and 1973 are contentious, and current abundance estimates are patchy. There are suggestions of metapopulation structure (even at the scale of $50 \mathrm{~km}$ ) in the western Atlantic among populations that do not appear to migrate. In the eastern Atlantic, data on population structure and migrations are few and confusing. Whales are incidentally caught in fishing gear and interact with fisheries off Labrador, Canada. They may also be affected by underwater noise. However, the population consequences of these and other anthropogenic stressors, particularly within this unknown metapopulation structure, are very uncertain. In some respects, such as the paucity of sightings on major whaling grounds off mainland Norway and Labrador, the picture that we have is disturbing. Analyses of genes, contaminants and vocalizations, as well as photoidentification and satellite tag data, can inform about population structure, migrations, life history parameters, current population sizes, and threats.
\end{abstract}

KEY WORDS: Northern bottlenose whale Ziphiidae $\cdot$ Population structure $\cdot$ Anthropogenic threat · Fisheries by-catch

\section{INTRODUCTION}

Whaling was a major global industry through the 18th, 19th and 20th centuries. In 1982, when the International Whaling Commission's (IWC) moratorium on commercial whaling was agreed, most large whale species were heavily depleted (Clapham et al. 1999, Whitehead 2002). Since then, some populations of some species have recovered, while others have not (Clapham et al. 1999).
The IWC officially sets quotas for the commercial catch of all species of baleen whale (Mysticeti) and 2 species of toothed whale: the sperm whale Physeter macrocephalus and the northern bottlenose whale Hyperoodon ampullatus (IWC Schedule Table 3, available at www.iwcoffice.org/cache/downloads/ 6awoj71tmhkw8gwows440k8kc/schedule.pdf). The northern bottlenose whale is the smallest of the whale species that was intensively hunted across its range. This range is the deeper waters of the north- 
ern North Atlantic (Fig. 1). Northern bottlenose whales were whaled heavily throughout this range in the period 1880 to 1920 , reprieved somewhat in the 1930s and then hunted again between 1937 and 1973. However, both the effects of whaling on the northern bottlenose and the current status of the species are extremely uncertain. These uncertainties stem from biological characteristics of the species.

The northern bottlenose whale is a beaked whale, family Ziphiidae, with one congener, the southern bottlenose whale Hyperoodon planifrons, which lives in the Southern Ocean. There are no subspecies. It is 7 to $9 \mathrm{~m}$ long, with mature males approximately $1 \mathrm{~m}$ larger than females (Benjaminsen \& Christensen 1979). The animals can live at least $37 \mathrm{yr}$ (Christensen 1973). Females become sexually mature at 8 to $13 \mathrm{yr}$ old and give birth to single offspring about every $2 \mathrm{yr}$ after a gestation of approximately 12 mo (Benjaminsen \& Christensen 1979). The species has 2 particularly unusual characteristics: they are among the deepest divers of all mammals, regularly descending to more than $800 \mathrm{~m}$ for $70 \mathrm{~min}$ or more (Hooker \& Baird 1999); and they also can be highly inquisitive, often approaching vessels (Mitchell 1977, Mead 1989).

Our knowledge of the biology of the northern bottlenose whale comes principally from analyses of

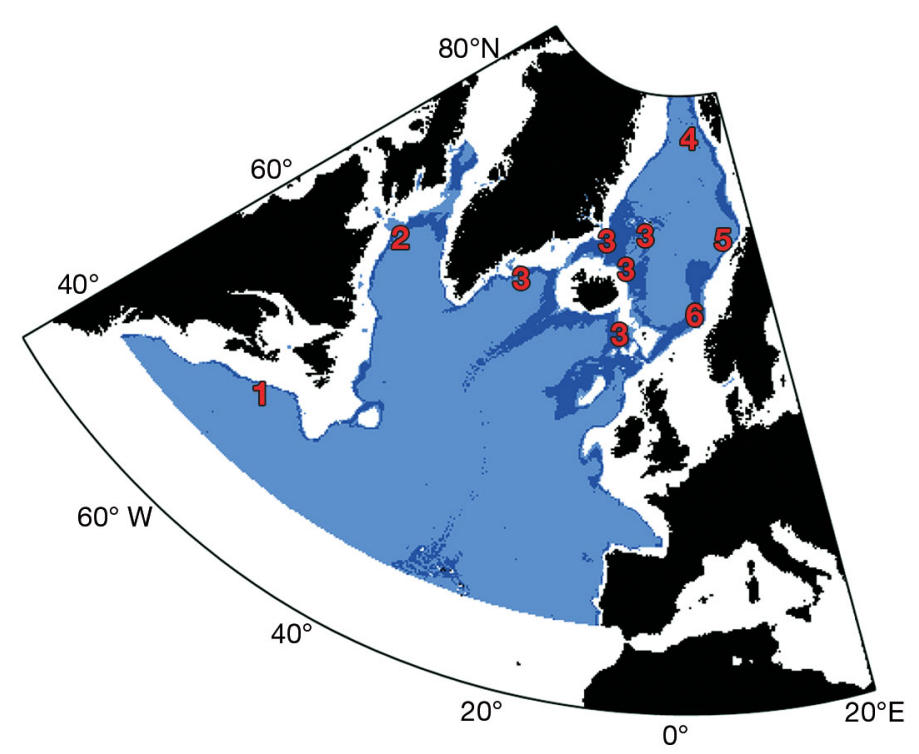

Fig. 1. General distribution of northern bottlenose whales in the North Atlantic (light blue), shown by waters greater than $500 \mathrm{~m}$ deep and north of $37.5^{\circ} \mathrm{N}$ (note: the northern parts of Baffin Bay and the Mediterranean Sea do not seem to be usual habitat for this species). Preferred habitat (800-1800 m deep) is shown in dark blue. The 6 centres of whaling operations are shown: (1) Scotian Shelf; (2) Labrador and southern Baffin Bay; (3) East Greenland, Iceland, Jan Mayen and the Faeroe Islands; (4) Svalbard; (5) Andenes; and (6) Møre specimens killed by Norwegian whalers (e.g. Benjaminsen 1972, Christensen 1973, Benjaminsen \& Christensen 1979), and research on living individually photoidentified animals off eastern Canada, particularly in 3 large submarine canyons, the Gully, Shortland Canyon and Haldimand Canyon, that indent the edge of the Scotian Shelf (e.g. Gowans et al. 2001, Hooker et al. 2002, Wimmer \& Whitehead 2004).

The biology of the bottlenose whale has been reviewed by Benjaminsen \& Christensen (1979) and Mead (1989). Its status has been considered several times, particularly by the Scientific Committee of the IWC 1976, 1988 and 2011, by the Committee on the Status of Endangered Wildlife in Canada (COSEWIC) in 1993, 1996, 2002 and 2011, and by the Scientific Committee of the North Atlantic Marine Mammal Commission (NAMMCO) in 1995. In these discussions, the status of this species has been contentious and uncertain, as reflected by an IUCN designation of Data Deficient (www.iucnredlist.org).

Here we update, combine and assess these efforts. Our review highlights a number of unresolved issues concerning status. Some of these issues, such as the effects of the second phase of whaling, have been debated for some time, while others, such as apparent differences in the resilience of the species in different areas, have not been much considered previously.

\section{DISTRIBUTION AND MIGRATIONS}

Northern bottlenose whales are found in waters of the North Atlantic north of approximately $37.5^{\circ} \mathrm{N}$ and deeper than approximately $500 \mathrm{~m}$ (Fig. 1), although they generally seem to prefer depths between 800 and $1800 \mathrm{~m}$, often along the continental slope (Benjaminsen \& Christensen 1979, Reeves et al. 1993, Wimmer \& Whitehead 2004, MacLeod et al. 2005). These water depths seem to coincide with the whales' dive depths (Hooker \& Baird 1999), suggesting that they often forage near the sea floor. In the Norwegian Sea, their distribution matches that of their presumed primary prey, Gonatus fabricii, quite well (Bjørke 2001). However, apart from the population found along the Scotian Shelf, and sporadic sightings off the Azores (Silva et al. 2003), they are rarely seen south of $55^{\circ} \mathrm{N}$. This species was whaled in 6 general areas across the northern North Atlantic (Fig. 1) (Mead 1989): (1) along the edge of the eastern Scotian Shelf, Canada, with effort focused on the Gully; (2) along the edge of the continental Shelf off northern Labrador, and in southern Baffin Bay, Canada; (3) a broad region off 
east Greenland, around Iceland, Jan Mayen and the Faeroe Islands; (4) southwest of Svalbard (Spitzbergen), Norway; (5) off Andenes, northern Norway; and (6) off Møre, western Norway.

Bottlenose whales are sometimes found in other parts of the northern North Atlantic (Benjaminsen \& Christensen 1979). For instance, there have been a number of sightings along the edge of the Canadian shelf between the Scotian Shelf and northern Labrador, in the central Norwegian Sea, off the British Isles, in the deeper, southern, waters of the Bay of Biscay, and off the Azores (Clarke 1981, Mead 1989, Reeves et al. 1993, Silva et al. 2003, MacLeod et al. 2004, Kiszka et al. 2007, Oien \& Hartvedt 2011).

Members of the Scotian Shelf population do not seem to make seasonal migrations. 'Pop-up' hydrophones placed in the Gully had similar rates of detecting northern bottlenose whales in all seasons (Moors 2012), and individuals that were photoidentified in the winter had also been identified in the same area in the summer (Whitehead et al. 1997b). Members of this population move among the 3 large canyons on the edge of the eastern Scotian Shelf (the Gully, Shortland Canyon and Haldimand Canyon, which are arranged along the shelf edge at intervals of approximately $50 \mathrm{~km}$ ) but a photoidentification analysis indicated that at least some individuals show preferences for particular canyons (Wimmer \& Whitehead 2004).

We know little about the movements or migrations of members of the Baffin-Labrador population. However, northern bottlenose whales have been sighted in the Baffin-Labrador area during winter, which seems to indicate that the entire population does not make pronounced seasonal migrations (Reeves et al. 1993).

It is also unclear whether bottlenose whales migrate seasonally in the northeastern Atlantic (Benjaminsen \& Christensen 1979). In the Norwegian Sea there are relatively more bottlenose whale sightings, compared with other species, between April and June, but they are sighted throughout the year (Oien \& Hartvedt 2011). Off the Faeroes, the whales strand and are caught year round, although there is a high season in August and September (Bloch et al. 1996). Strandings on the shores of Europe and Ireland are principally in late summer and autumn (Fraser 1953, MacLeod et al. 2004, Rogan \& Hernandez-Milian 2011). These types of observations have led to suggestions that eastern North Atlantic bottlenose whales move northward in spring and southward in autumn (Gray 1882, Christensen 1993, MacLeod et al. 2004). However, animals were caught in substantial numbers off Scotland in June (Thompson 1928) and are seen in the Azores, one of their most southerly locations, in summer (Clarke 1981, Silva et al. 2003). It is possible that instead of pronounced north-south seasonal migrations, there are seasonal inshoreoffshore movements as the whales track changing abundance of particular food sources.

\section{POPULATION STRUCTURE}

The 6 areas of concentration listed in the previous section all potentially represent distinct populations, and there could be others. For convenience, and on the basis of differing catch histories, some scientists divided the population into 2 stocks, in the northeast and the northwest Atlantic, separated by the longitude of Cape Farewell, the southern tip of Greenland (e.g. Mitchell 1977). However, there was no biological basis for this division, and, with a total lack of information on stocks, in 1976 the Scientific Committee of the IWC left the population undivided (International Whaling Commission 1977b).

We now have information on relationships between animals in 3 of the areas of whaling concentration. Using $434 \mathrm{bp}$ of the mitochondrial DNA (mtDNA) control region and 10 microsatellites, Dalebout et al. (2006) compared samples from the Scotian Shelf $(\mathrm{n}=$ $34)$, off Labrador $(n=127)$ and Iceland $(n=23)$. The Scotian Shelf and Baffin-Labrador samples were differentiated by both microsatellites $\left(F_{\mathrm{ST}}=0.0243\right.$, p < $0.0001)$ and mtDNA $\left(\Phi_{\mathrm{ST}}=0.0456, \mathrm{p}<0.05\right)$. This analysis estimated less than 2 individuals moving between these areas per generation (Dalebout et al. 2006). The differentiation (as indicated by $F_{\mathrm{ST}}$ using the microsatellites) between the animals from the Scotian Shelf and the Baffin-Labrador populations was similar for males and females. The Icelandic samples appeared distinct from those of the Scotian Shelf (microsatellites: $F_{\mathrm{ST}}=0.0276, \mathrm{p}<0.0001$; mtDNA: $\Phi_{\mathrm{ST}}=0.0315, \mathrm{p}=0.12$ ), but not from those from Baffin-Labrador (microsatellites: $F_{\mathrm{ST}}=0.0000$, $\mathrm{p}=0.40 ;$ mtDNA: $\Phi_{\mathrm{ST}}=-0.0150, \mathrm{p}=0.72$ ).

Other evidence corroborates differentiation between the animals off the Scotian Shelf and in the Baffin-Labrador area. Animals measured off the Scotian Shelf (451 photographic measurements with some resampling, and 25 killed by whalers) were approximately $0.7 \mathrm{~m}$ shorter on average than the 127 killed by whalers in Baffin-Labrador (Whitehead et al. 1997b). The calving season seems to be centred around August on the Scotian Shelf (Whitehead et al. 1997a), and April in Baffin-Labrador (Benjaminsen 
1972). There are no photoidentification matches between the Scotian Shelf, where most of the population is photoidentified, and the 9 photoidentifications from Baffin-Labrador (COSEWIC 2011). Contaminant analysis of 3 animals sampled from the BaffinLabrador population and 33 samples from the Scotian Shelf population showed significant differences in both expression of CYP1A1 (a biomarker for exposure to some contaminants including polycyclic aromatic hydrocarbons) and measured blubber contaminants (see Hooker et al. 2008 and section 'Contaminants' below). Finally, the photoidentification of animals on the Scotian Shelf provides a mark-recapture estimate of 163 animals (Whitehead \& Wimmer 2005). If there were frequent exchange of animals between the Scotian Shelf and Baffin-Labrador, then this would imply a very small total population indeed for such a large range (Whitehead \& Wimmer 2005, COSEWIC 2011).

Thus, there is good evidence that the Scotian Shelf and Labrador-Baffin contain well-separated populations, and indications of linkages between LabradorBaffin and Iceland. We know of no other evidence of potential stock relationships among the historic population centres of this species.

\section{FEEDING, BEHAVIOUR AND SOCIAL STRUCTURE}

Northern bottlenose whales eat various deepwater fishes and squids (Mead 1989). However, their principal prey are squid of the genus Gonatus, giving them a particularly narrow ecological niche compared with other deep-diving mammals (Whitehead et al. 2003). In more northern parts of their range their primary food seems to be G. fabricii (Mead 1989, Bjørke 2001), whereas off the Scotian Shelf it is thought to be G. steenstrupi (Hooker et al. 2001). To catch these prey, the animals make deep dives: whalers have reported harpooned individuals diving for over $2 \mathrm{~h}$ (Gray 1882); and over $30 \mathrm{~h}$ of dive data from time-depth recorders deployed in the Gully showed that dives to $>800 \mathrm{~m}$ for 30 to $40 \mathrm{~min}$ were routine, with a maximum depth of $1450 \mathrm{~m}$ (Hooker \& Baird 1999). After a long dive, whales surface for 10 min or more blowing regularly, but they may remain near the surface for hours at a time.

The animals often socialize at the surface between dives, forming labile groups of approximately 1 to 10 animals containing any mix of age and sex classes. Their social structure appears generally similar to that of coastal populations of bottlenose dolphins Tursiops spp. (Gowans et al. 2001): females possess a loose network of relationships while there are strong bonds between pairs of males. The well-known inquisitiveness of the species (Mead 1989), as well as its social structure, may be related to the consistent use of what are, by cetacean standards, small ocean areas (Gowans et al. 2001). Their social bonds and tendency to approach vessels were exploited by whalers, who mounted harpoon guns at both the bows and sterns of their vessels (Mitchell 1977), and would harpoon and injure one animal to entice the group to remain nearby (since they would often not desert an injured companion), enabling them to take the entire group (Reeves et al. 1993).

\section{WHALING AND ITS EFFECTS}

We summarize the history of whaling for northern bottlenose whales in Table 1 and Fig. 2 (for more detailed information, see Benjaminsen 1972, Christensen \& Ugland 1983, Christensen 1993, Reeves et al. 1993, Oien \& Hartvedt 2011). There may be unrecorded catches, especially in the early years of the hunt, when statistics were not collected routinely.

Table 1. Approximate numbers of bottlenose whales caught by different hunts in different population centres of the North Atlantic (from Benjaminsen 1972, Christensen \& Ugland 1983, Reeves et al. 1993, Bloch et al. 1996), based upon Table 2 of International Whaling Commission (2012). Gaps indicate no data available (it is assumed that there are no catches)

\begin{tabular}{|c|c|c|c|c|c|c|c|c|}
\hline Whalers & Dates & $\begin{array}{l}\text { Scotian } \\
\text { Shelf }\end{array}$ & $\begin{array}{l}\text { Labrador- } \\
\text { Baffin }\end{array}$ & $\begin{array}{l}\text { Iceland/ } \\
\text { E. Greenland }\end{array}$ & Faeroes & Svalbard & $\begin{array}{l}\text { Andenes, } \\
\text { Norway }\end{array}$ & $\begin{array}{c}\text { Møre, } \\
\text { Norway }\end{array}$ \\
\hline Faeroe Is. & 1584-1993 & & & & 740 & & & \\
\hline UK & 1856-1893 & & 264 & 1643 & & & & \\
\hline Norway & $1882-1930$ & & & $<$ & 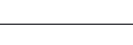 & $-56389^{a}$ & & $\longrightarrow$ \\
\hline Norway & 1937-1973 & & & 2277 & & 1795 & 241 & 740 \\
\hline Norway & 1969-1971 & & 818 & & & & & \\
\hline Canada & 1962-1967 & 87 & & & & & & \\
\hline
\end{tabular}



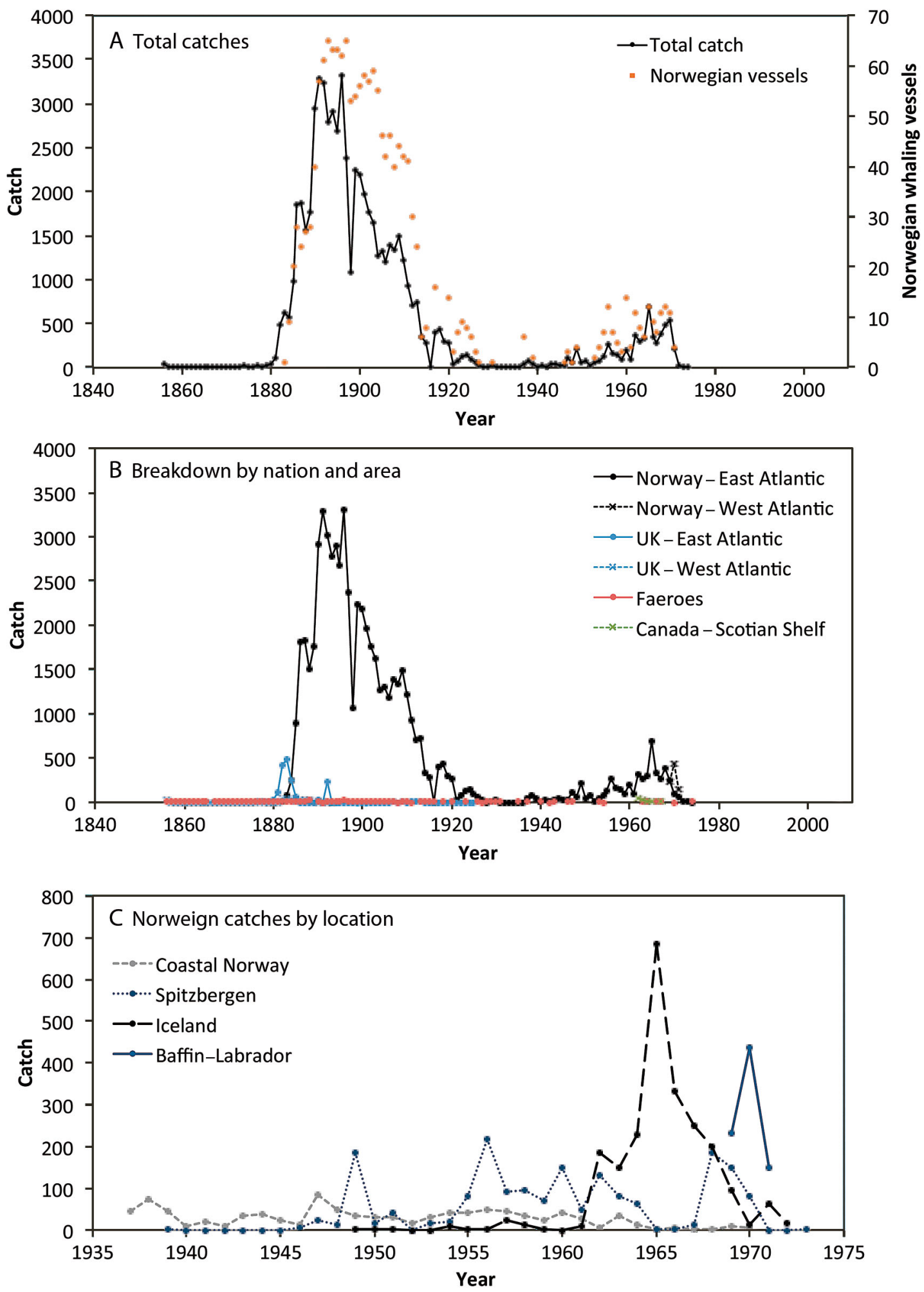

Fig. 2. Reported annual catches (in number of individuals) of northern bottlenose whales. (A) North Atlantic total, with number of Norwegian vessels operating per year presented as an indication of whaling effort (Christensen \& Ugland 1983, Reeves et al. 1993, Bloch et al. 1996). (B) Breakdown by nation and area (western and eastern North Atlantic divided at the southern tip of Greenland). Reported UK catches in the western Atlantic were very small. (C) Increased detail of the second phase of eastern Atlantic whaling, showing the westward expansion of whaling. Note: because of systematic changes in the nature of the hunt, including technological changes, using the number of whaling vessels as a measure of effort is only valid for compari- 
'Struck-and-loss' (i.e. animals killed but not captured) may also have been substantial in these early years when many of the whalers were using small vessels without engines, which likely reduced the landing rates of dead or mortally injured whales compared with that of the larger powered vessels that were used later (Christensen 1993).

There has been a drive fishery in the Faeroe Islands that has taken occasional bottlenose whales for many centuries. Bloch et al. (1996) found reports of 648 bottlenose whales being driven and 92 shot offshore between 1584 and 1993. Whaling for bottlenose whales officially became illegal in the Faeroes with the IWC's moratorium in 1986. However, the rate of reported strandings rose substantially, with 3 reported between 1910 and $1986\left(0.04 \mathrm{yr}^{-1}\right)$, rising to 6 in 1987-1993 (1.0 $\left.\mathrm{yr}^{-1}\right)$ (Bloch et al. 1996) and 22 between 2000 and 2010 (2.2 $\mathrm{yr}^{-1}$ ) (www.vmr.fo/ Default.aspx?ID=7125).

Scottish vessels that targeted seals as well as occasional whales began to hunt northern bottlenose whales in 1852, but the hunt seems to have commenced in earnest approximately 25 yr later (Christensen \& Ugland 1983, Mead 1989). The Scots whaled in the northwestern Atlantic, especially in the Davis Strait, as well as in the Greenland Sea in the northeast Atlantic (Reeves et al. 1993). However, the hunt for bottlenose whales was soon taken over by Norwegians, who, it is estimated, took approximately 56389 whales between 1882 and the late 1920s from whaling grounds in the northeastern Atlantic (Christensen \& Ugland 1983; our Table 1). The Norwegians restarted bottlenose whaling in the late 1930s as part of their North Atlantic hunt for 4 species of small whale. They caught bottlenose whales across the eastern North Atlantic but particularly in the 4 northeastern Atlantic centres of concentration shown in Fig. 1, taking approximately 5053 whales between 1937 and 1973 (Benjaminsen 1972, Christensen \& Ugland 1983). Between 1969 and 1971, the Norwegian whalers turned their attention to the Baffin-Labrador population, killing 818 animals (Christensen 1975, Reeves et al. 1993). Canadian whalers took 87 northern bottlenose whales from the Scotian Shelf area between 1962 and 1967 (Reeves et al. 1993). There is some current whaling for the species off West Greenland. Greenlanders took 9 animals in 2007, 21 in 2008, and 1 in 2009 (NAMMCO 2012).

The overall catch trajectory (Fig. 2) is characteristic of an overexploited resource: a rapid rise in effort and catch, peaking in 1896, followed by a steady, almost linear, decline (that is lagged by a drop in the number of whaling ships) until whaling became uneconomic in the early 1930s. A secondary peak in the 1960s might be attributable to a combination of some population recovery, improvements in technology, and new markets allowing economic exploitation to resume. With the exception of the occasional catches off the Faeroe Islands and Greenland, bottlenose whaling died out in the early 1970s as the UK banned the import of meat from these animals to be used as pet food, Norway found cheaper sources of food for the animals in its fur industry, minke whales Balaenoptera acutorosrata became relatively more valuable, and antipathy to commercial whaling grew globally (see Jonsgård 1977). Except for a final burst off Labrador between 1969 and 1971, the majority of bottlenose whaling was in the northeast Atlantic (Fig. 2).

Using rough catch-per-unit-effort methods, Holt (1977) estimated a pre-whaling population of $\sim 130000$ reduced to $\sim 2000$ in 1913, and Christensen \& Ugland (1983) estimated a population of 90 000 reduced to $\sim 30000$ in 1914 for the northeast Atlantic. There are general difficulties with using such methods on whaling data (e.g. Cooke 1985), including changes in technology, increases in knowledge by the hunters, as well as variability in, and systematic changes to, the behaviour of the whales. These may be exacerbated in the case of the northern bottlenose whale by species-specific issues such as uncertainty about stock structure and possible changes in the whales' natural inquisitiveness as whaling progressed. In 1995, the Scientific Committee of NAMMCO carried out a more sophisticated 'hitter' analysis for the northeast Atlantic, in which the recorded catch series, assumptions about the population biology of the species, and recent population estimates were used to produce population trajectories. The results of this analysis were very varied, suggesting initial populations between $~ 35000$ and 110000 , and a population status in the 1990s ranging from fully recovered to still severely depleted (NAMMCO 1995). The uncertainty in initial population size largely stems from a lack of knowledge of the population size in the 1990s, as well as the life history parameters of the species. However, the analyses strongly suggest that the population abundance was very low at the end of the first phase of whaling in the 1920s.

During the 1970s there was scientific dispute at the Scientific Committee of the IWC as to whether the largely Norwegian second phase of the hunt, post 1930s, had depleted the species substantially across its range (Christensen et al. 1977, Holt 1977, Mitchell 
1977). There were 2 perspectives (International Whaling Commission 1977a). Norwegian scientists showed that catch-per-unit-effort did not decline between 1946 and 1962, although there was some decline in the northeast Atlantic in the 1960s. They explained that the expansion of the Norwegian whaling into the distant Labrador grounds between 1969 and 1971 was made possible by new larger vessels that entered the hunt in the late 1960s, that this expansion was driven by the search for 'new' grounds for catching minke whales (that were caught along with the bottlenose whales), and that although there was some decline in catch-per-unit-effort off Labrador, it was not very substantial. They attribute the end of bottlenose whaling in the 1970s entirely to market forces rather than depletion of the population (Christensen et al. 1977). Following this line of argument, Christensen \& Ugland (1983) later estimated an approximate doubling of the northeast Atlantic population between 1914 and 1976 to 54000 animals in the 1980s. In contrast, other members of the 1976 Scientific Committee emphasized that during the second phase of Norwegian whaling, effort moved consistently away from the home bases of the whalers (Fig. 2), with catch numbers peaking in 1938-1941 off Andenes, 1954-1957 off Møre and Svalbard, 1962-1965 off Iceland and 1969-1971 off Labrador (see Benjaminsen 1972). This is a classic signal of overexploitation (Mitchell 1977). Mitchell (1977) also argued that the drop in catches preceded the drop in price of the product, and thus that the species was depleted at the end of the whaling era in the early 1970s.

Stranding rates may indicate the trajectory of bottlenose whale population sizes (Fig. 3). Off the Faeroe Islands, there were reports of approximately 6 unassisted strandings per decade between 1840 and 1900, but only a total of 3 between 1910 and 1990, in other words a rate of 0.4 per decade (Bloch et al. 1996). In contrast to this pattern suggesting major depletion around the Faeroes between 1910 and 1980 , stranding rates off Ireland between 1880 and 2000 (Rogan \& Hernandez-Milian 2011) and off the UK between 1913 and 1992 were fairly stable (Fig. 3). A dramatic rise in strandings in all 3 locations after 2000 (Fig. 3) may not be attributable to increased populations, as the stranding rates of other beaked whale species (that had not been hunted) rose even more dramatically in this decade (Rogan \& Hernandez-Milian 2011), suggesting either increased probabilities of reporting strandings or natural or anthropogenic environmental changes that generally increased beaked whale stranding rates. The lack of correspondence in stranding trajectories between the Faeroes versus the UK and Ireland might suggest that the Faeroese pattern is an anomaly, or that the whales form small local populations, as found off the Scotian Shelf, so that those off Ireland or the UK were not much affected by the heavy whaling in the Faeroes-Iceland area (which depressed the number of strandings in the Faeroes).

Overall, it seems that there were of the order of 100000 northern bottlenose whales before whaling began in earnest in the late 19th century, and that this population had been substantially depleted by the First World War. The continued whaling between 1918 and 1930 precluded much recovery and may have depleted the population further (International Whaling Commission 1977a). The results of the second phase of whaling are particularly uncertain, but perhaps a few tens of thousands were left in the 1970s after whaling had ceased.

\section{CURRENT POPULATION STATUS}

\section{Scotian Shelf}

Whitehead \& Wimmer (2005) used photoidentification data collected between 1988 and 2003 in the Gully, and a model that incorporates heterogeneity in identifiability and corrects for animals that have no reliable marks, to assess the Scotian Shelf population. They estimated a mean population size of 163

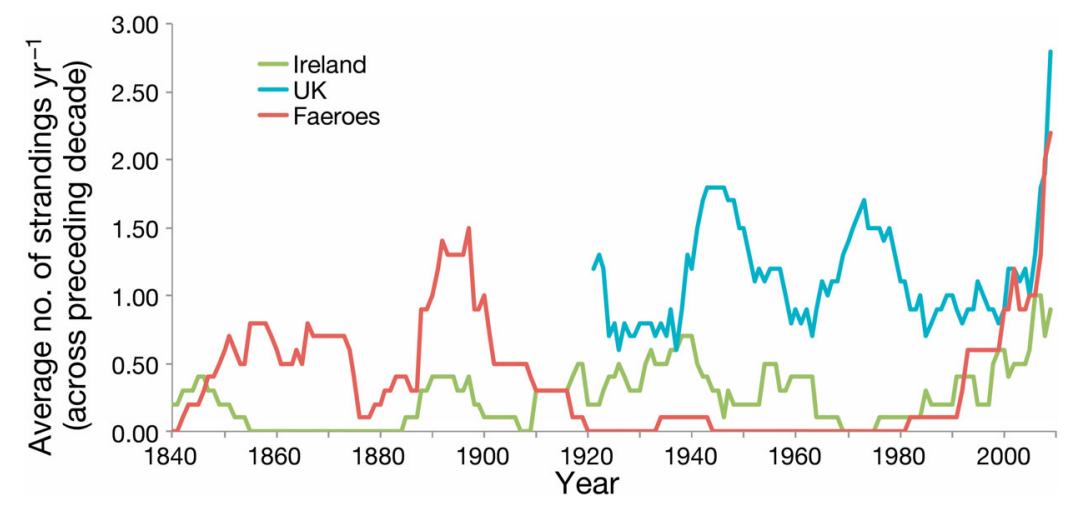

Fig. 3. Rates of strandings from the Faeroes (data from Bloch et al. 1996, www.vmr.fo/Default.aspx?ID=7125), Ireland (data from Rogan \& HernandezMilian 2011) and the UK (data from Natural History Museum and Zoological Society London available from 1913). The moving average calculated for the decade preceding each year is shown 
adult and immature animals (95\% confidence inter$\mathrm{val}=119-214)$. An updated analysis using data up until 2009 made virtually no change to these estimates (COSEWIC 2011). In both analyses, models that included a trend in population size with time had less support (as indicated by Akaike's information criterion) than those that assumed a stable population. However, the models that did include a trend parameter indicated that the population is growing at a rate of approximately $2.1 \%$ per year $(95 \%$ confidence interval $=-1.6$ to $+6.3 \% \mathrm{yr}^{-1}$ ).

We do not know whether the Scotian Shelf population has recovered from the catch of 87 animals in the 1960 s, which would account for approximately $53 \%$ of the current population size. Observations of calves of the Scotian Shelf population indicate a low reproductive rate: of 3113 sightings of northern bottlenose whales close enough to the research vessel to be photoidentified $(\leqslant 100 \mathrm{~m})$ in the Gully between 1988 and 1999 , only $6 \%$ were recorded as first-year calves (COSEWIC 2011). There was no signal of a population bottleneck in the molecular genetic analyses (Dalebout et al. 2006).

The small size of the Scotian Shelf population, together with the anthropogenic threats that it faces (see 'Current threats'), led the Committee on the Status of Endangered Wildlife in Canada to list this population as Endangered in 2002. It was added to Appendix 1 of Canada's Species at Risk Act with this designation in 2006 (COSEWIC 2011).

\section{Baffin-Labrador}

Since the heavy whaling of 1969 to 1971 , a number of northern bottlenose whales have been sighted in the Baffin-Labrador area (Reeves et al. 1993, Herfst 2004, MacDonald 2005), and fishermen working in the area frequently report sightings (COSEWIC 2011). However, northern bottlenose whales were sighted just once during the portions of the TransNorth Atlantic Sightings Survey (T-NASS) aerial surveys flown off Labrador in 2007 (5363 km flown south of the northern tip of Labrador). This contrasts with 9 sightings off eastern and southern Newfoundland (17998 km flown) and 3 off the Scotian Shelf (9111 km flown) (Lawson \& Gosselin 2009). Additionally, very few animals were sighted in the LabradorBaffin region during boat surveys targeting northern bottlenose whales that were carried out in 2003 and 2004 (Herfst 2004, Compton 2005). During these surveys, the encounter rate was 0.03 encounters per hour off Labrador versus 0.50 for the Gully, 0.29 for
Shortland Canyon and 0.14 for Haldimand Canyon on the edge of the Scotian Shelf (COSEWIC 2011). MacDonald (2005) recorded 6 encounters during $25.5 \mathrm{~h}$ of effort during a survey aboard a fisheries research vessel in southern Baffin Bay/Davis Strait in 2004. However, 4 of these encounters occurred while the vessel was fishing, and northern bottlenose whales are attracted to fishing vessels in the area. Overall, then, the status of the Baffin-Labrador population is uncertain but, given sighting rates lower than for the Scotian Shelf population which numbers approximately 160 animals, there are grounds for concern that it has not recovered from the heavy whaling of 1969 to 1971 . These concerns led the Committee on the Status of Endangered Wildlife in Canada to list this population as of Special Concern in 2011 (COSEWIC 2011).

\section{Iceland and Faeroes}

Shipboard surveys for cetaceans were carried out in the waters surrounding Iceland in 1987, 1989, 1995, 2001 and 2007. Based on 92 sightings of northern bottlenose whales in 1987, Gunnlaugsson \& Sigurjónsson (1990) estimated a population size of 4925 $(\mathrm{CV}=0.16)$ off Iceland and $902(\mathrm{CV}=0.45)$ off the Faeroes. Pike et al. (2003) estimated $27900(\mathrm{CV}=$ $0.67)$ for the 1995 survey and $28000(\mathrm{CV}=0.22)$ for that in 2001. There has been no estimate from the 2007 Icelandic T-NASS data in which 26 animals were sighted in the general area of Iceland. However, Cañadas et al. (2011) analyzed the data from the Faeroese 2007 T-NASS ship surveys as well as the 2007 Cetacean Offshore Distribution and Abundance in the European Atlantic (CODA) surveys, which covered the deeper waters west of Great Britain, Ireland, France and northern Spain. Cañadas et al. (2011) estimated $16284(\mathrm{CV}=0.41)$ northern bottlenose whales in the waters around the Faeroes based upon 12 sightings, and $3254(\mathrm{CV}=0.70)$ in the CODA study area based upon 3 sightings.

These estimates are biased downwards because of the long dives of the whales, and upwards because of ship attraction (Reeves et al. 1993, Barlow et al. 2005). Sightings surveys could be corrected for diving behaviour using information on bottlenose whale dives (Hooker \& Baird 1999), and this has been attempted (NAMMCO 1993). While bottlenose whales are most clearly attracted to small, stationary vessels, they sometimes approach larger vessels underway (Mitchell 1977). Ship attraction causes 2 problems: first, more animals are sighted than would be 
expected if the animals were not affected by the presence of the vessel; and second, they are sighted closer to the transect line, thus lowering the estimated effective sighting distance. Both will inflate estimates of density and population size. These problems were discussed at the 2011 meeting of the Scientific Committee of the IWC, and there are different perspectives on the severity of their effects on abundance estimates (International Whaling Commission 2012). For instance, it was noted that in the surveys reported by Cañadas et al. (2011), there was no evidence for animals responding to the survey vessel. However, if, as is sometimes observed in the Gully (authors' personal observation), whales approach vessels directly from depth, there would be no evidence of such attraction from survey data. Thus, correcting ship-survey abundance estimates for ship attraction is problematic, and, for now, these estimates should be treated cautiously. However, despite these issues with the abundance estimates, the survey results show that numbers of bottlenose whales live in the waters off Iceland and the Faeroes.

\section{Norway: Andenes and Møre}

There are no estimates of density or abundance for the 2 areas where whaling effort has been concentrated off mainland Norway (Fig. 1). Oien \& Hartvedt (2011) compiled sightings of the species in Norwegian surveys, as well as incidental reports, but gave no measures of effort. All 66 sightings during surveys between 1987 and 2010 were far out in the Norwegian Sea, most between Iceland and Svalbard, and none in either the Andenes or Møre whaling grounds. Of 166 incidental sightings collected between 1967 and 2010, 3 were on or close to the Andenes grounds and none were on or close to the Møre grounds. A cetacean tourism operator in the Andenes area describes northern bottlenose whale as 'very rare...in these waters' (http://arcticwhaletours.com/?p=952).

Without focused studies or well-planned surveys, the status of the bottlenose whale on these 2 old Norwegian whaling grounds is uncertain. However, the information available is worrying, with no indication of recovery, and only faint signs of extant populations.

\section{Svalbard}

The situation off Svalbard is more encouraging. Oien \& Hartvedt (2011) plot a fair number of both incidental and survey sightings of the species in the waters south and east of Svalbard. There is no particular geographical delineation of a 'Svalbard concentration' so we cannot give precise numbers. However, in 2100 nautical miles of ship survey during 2005 in the 'Small Management Area ES', which includes the northern Norwegian Sea, the Greenland Sea and the Svalbard area west of $28^{\circ} \mathrm{E}$ and north of $73^{\circ} \mathrm{N}, 21$ northern bottlenose whales were sighted (2005 NAMMCO Norway Progress Report), and in 2008 twelve northern bottlenose whales were sighted over 2780 nautical miles of a ship survey (2009 NAMMCO Norway Progress Report). The Andenes-based whale-watching operation notes that northern bottlenose whales are sighted from time to time in the Svalbard region (http://arcticwhaletours. $\mathrm{com} / \mathrm{p}=952$ ).

\section{CURRENT THREATS}

Northern bottlenose whales seem to face 2 principal threats: bycatch/entanglement in fishing gear, and ocean noise. Both these threats are actual, but in each case the extent of harm is uncertain. We also have concern about the effects of contaminants. The pattern of eastern Atlantic strandings suggests that there may have been a recent increase (since the 1990s) in causative anthropogenic threats (Fig. 3). MacLeod (2009) predicts that as waters warm with global climate change, available habitat for northern bottlenose whales will change, and possibly, there will be an overall decline.

\section{Interactions with fisheries}

There are reports of northern bottlenose whales interacting with fisheries off Iceland (Víkingsson et al. 2009), on the Scotian Shelf, and especially with offshore trawling and long-lining operations for Greenland halibut Reinhardtius hippoglossoides in Baffin-Labrador waters (COSEWIC 2011). Fishermen report that the whales remove the bait or catch off the lines (COSEWIC 2011).

In 2009, the Canadian Department of Fisheries and Oceans had 5 records of entanglement of northern bottlenose whales from the Scotian Shelf area and 3 from Newfoundland/Labrador since the early 1980s. These entanglements were in fisheries using benthic and pelagic long-lines and otter-trawls set for swordfish Xiphius gladius, silver hake Merluccius bilinearis, Greenland halibut and squid (Department of 
Fisheries and Oceans 2009). Some of the entangled animals were cut free, and may have survived. Others died, or appeared so severely entangled to make survival unlikely (Gowans et al. 2000). One died from entanglement in fishing gear off Iceland in 2008 (Víkingsson et al. 2009). There are certainly unreported entanglements, but their frequency and severity are unknown.

\section{Noise}

There are several potential effects of underwater anthropogenic noise on cetaceans. These include behavioural disturbance, displacement, temporary or permanent changes to hearing thresholds, masking of important sounds, and death from noise-induced stranding (Nowacek et al. 2007). Almost all research into the effects of anthropogenic noise on cetaceans has examined short-term effects, and the results of different studies have sometimes appeared contradictory (Nowacek et al. 2007). Furthermore, there has been very little directed research on the effects of noise on northern bottlenose whales. Thus, the impact of anthropogenic noise on this species is extremely uncertain.

Geophysical seismic surveys are sporadically intense in the habitat of northern bottlenose whales, and constitute the noise source most of concern for this species. Seismic survey noise might cause northern bottlenose to move from preferred habitat or disrupt their foraging. Cetacean species often move away from seismic surveys (Stone 2003), and the foraging of sperm whales, which also dive deep for squid, seems negatively affected by seismic pulses (Miller et al. 2009).

There has been sporadic but sometimes intense seismic exploration activity in the habitat of the northern bottlenose whale. This is an issue much discussed for the Scotian Shelf population (Department of Fisheries and Oceans 2009). The animals' prime habitat, the Gully, was declared a Marine Protected Area in 2004, and no longer has seismic exploration. However, during a 2003 seismic survey being carried out approximately $50 \mathrm{~km}$ from the Gully, received noise levels were approximately 135-140 dB re. $1 \mu \mathrm{Pa}$ SEL inside the Gully (McQuinn \& Carrier 2005), but bottlenose whales were sighted in the Gully during the survey (Gosselin \& Lawson 2005). Seismic surveys take place sporadically in other important habitat for Scotian Shelf northern bottlenose whales. The principal habitat of the BaffinLabrador population is further north than most seis- mic exploration off the Labrador coast. The whales' habitat off the UK and Norway has been subject to seismic exploration (see www.og.decc.gov.uk/ environment/opachr.htm and www.pdp.diskos.com). Seismic exploration has been particularly frequent over the old Møre whaling grounds off western Norway, and quite frequent near Svalbard, but relatively rare around the Andenes whaling grounds.

There has been particular concern about the effects of military sonar and other naval activities which are known to cause strandings and deaths of beaked whales (Cox et al. 2006, Weilgart 2007). There is a record of one northern bottlenose whale in a mass stranding off the Canary Islands seemingly triggered by military activities (Simmonds \& LopezJurado 1991). Most northern bottlenose whales live far from well-populated coasts, so many strandings would likely be unreported. We do not understand how the anthropogenic sounds kill the whales. Theoretical studies by Houser et al. (2001) and Hooker et al. (2009) suggest that long and deep dives may make animals particularly susceptible to acoustically triggered physiological damage through the accumulation of nitrogen in the tissues and blood. However, Hooker et al. (2009) suggest that northern bottlenose whales may be less at risk than Cuvier's beaked whales.

\section{Contaminants}

Hooker et al. (2008) measured the levels of several types of contaminants in northern bottlenose whales from both the Scotian Shelf and Baffin-Labrador. Overall levels were comparable to those found in other North Atlantic odontocetes. Contaminant concentrations have been reported for bottlenose whales in the eastern Atlantic for a juvenile male that stranded in the North Sea in 1976. This animal contained higher quantities of PCBs and approximately the same quantity of DDTs compared with animals sampled in the Gully (Harms et al. 1978). However, there may be problems with such comparisons, given recent advances in analytical techniques (Hooker et al. 2008).

\section{DISCUSSION}

It seems that there were of the order of 100000 northern bottlenose whales in the mid-19th century, and that by 1920, British and Norwegian whalers had reduced the population very substantially. Much else 
about the status of the species is uncertain. Some results from the only detailed study of the living animals off the Scotian Shelf in the western North Atlantic seem at odds with data collected during whaling operations in other areas. In several regards, our review leaves questions rather than answers.

\section{How is the species structured: metapopulations or migrations?}

The conservation status of any species is highly dependent on how it is structured geographically. The potential geographical structures attributed to the northern bottlenose whale are about as wide as they could be. At one extreme, in 1976 the Scientific Committee of the IWC rejected Mitchell's (1977) suggestion that the species be separated into 2 stocks (eastern and western stocks divided at Cape Farewell) in favour of a single undifferentiated stock, on the basis that there were no data indicating stock divisions (International Whaling Commission 1977b). In contrast, while photoidentified animals move among 3 large canyons spaced at approximately $50 \mathrm{~km}$ intervals along the edge of the Scotian Shelf, many individuals show preferences for particular canyons, indicating important population structure at about this scale (Wimmer \& Whitehead 2004). The genetic, contaminant and other data that we have summarized above show clear differences between the populations off the Scotian Shelf and northern Labrador, about $2800 \mathrm{~km}$ apart, despite sightings of whales off the Grand Banks, lying between these 2 areas. The different 20th century stranding trajectories off the Faeroes, Ireland and the UK (Fig. 3), about $800 \mathrm{~km}$ apart, might indicate that these areas contain populations with little interchange and, thus, largely independent population trajectories affected differentially by factors such as whaling centred in the FaeroesIceland area. In contrast, the apparently seasonal nature of the species' occurrence in several areas of the northeast Atlantic could, as often suggested, be consistent with a largely undifferentiated population making seasonal migrations. There could be mixtures of migration strategies within populations, with some individuals, age or sex classes migrating large distances, some small distances and some not at all.

There are well-established methods for examining population structure and migration in cetaceans, some of which have been used in examining the relationships between the Scotian Shelf and BaffinLabrador populations, and all of which should be considered as we address population structure throughout the species' range. Attention should be directed at the areas where whaling was concentrated, as well as other areas where depths are suitable and the species has been reported (Fig. 1). Molecular analyses give data on evolutionary divergences in the population as well as estimates of rates of transfer between areas (Dalebout et al. 2006). Studies of vocalizations can indicate cultural divisions (e.g. McDonald et al. 2006), contaminants and isotope ratios suggest habitat differences (e.g. Hooker et al. 2001, 2008), while photoidentifications and satellite tags can track the movements of individuals (e.g. Dufault et al. 1999, Mate et al. 2007). Fixed hydrophones have been used successfully to monitor seasonal and geographical changes in the distribution of the Scotian Shelf animals (Moors 2012), and would produce informative results if used elsewhere.

These methods are complementary, each looking at different types of population structure, with different time scales and management implications. All can indicate the extent of migratory behaviour, but satellite tags, analyses of trace elements and photoidentification matches, or the lack of them, will be particularly useful.

\section{What was the effect of the second phase of bottlenose whaling between 1930 and 1973 ?}

While the initial pulse of bottlenose whaling, in which approximately 58000 animals were killed between 1880 and 1920, clearly depleted the population, the effects of the second phase, with approximately 6000 catches between 1930 and 1973, are not agreed. On the one hand, if the 1930 population was small, say 10000 to 20000 animals, then it is probable that it was further depleted by 1973, and this is indicated by the general movement of the whaling operations away from their home bases (Holt 1977, Mitchell 1977). On the other hand, if there were still of the order of 50000 whales in the population in 1930, then the subsequent whaling may have only slowed the recovery (Christensen \& Ugland 1983). Attempts to model this (see NAMMCO 1995) depend on knowledge of the catch history, the current population size and the life history parameters of the whales. While the catch history may have some errors, particularly with unreported catches and 'struck-and-loss' whales early in the exploitation, it is probably a fairly accurate representation of direct anthropogenic removals. Uncertainty about the effects of the second phase of whaling is driven by the lack of an accurate current population size, as 
well as scant information on the life history parameters of the species. Some life history detail was obtained from the Norwegian analysis of the Labrador catch (Benjaminsen 1972, Benjaminsen \& Christensen 1979), but it is unfortunately insufficient to drive an informative analysis of the population trajectory and status of this species (NAMMCO 1995). Perhaps the best route towards improved knowledge of life history parameters would be from the synthesis of detailed data on individually identified animals (e.g. Olesiuk et al. 1990). This might, in time, be possible for the Scotian Shelf population, but would be difficult for the more remote populations.

\section{What is the current population size, and how can we assess it?}

While we have a fairly robust estimate of population size and trend for the Scotian Shelf population, abundance in other parts of the species' range is unknown or based upon uncorrected visual surveys. Raw population estimates from visual ship surveys will be negatively biased due to long dives, and positively biased due to attraction to boats (Reeves et al. 1993, Barlow et al. 2005). The latter is particularly hard to correct, especially as the degree of attraction may vary with many factors including location, season, and the type and speed of the survey vessel. Aerial surveys only face the deep-diving bias, but this lowers the sighting rate so that population estimation may not be feasible, even with large well-planned surveys (Lawson \& Gosselin 2009). NAMMCO concluded that the total of 50 aerial and shipboard 'sightings made during [the large scale and well-planned 2007] T-NASS will be reported as distribution data only because there are not enough points for an abundance estimate' (NAMMCO 2009, p. 165).

Mark-recapture using photoidentifications is the best technique in current use for estimating bottlenose whale abundance, and the whales' inquisitiveness makes it more efficient in terms of photoidentifications per unit effort than is usual in cetacean studies. The estimates need to incorporate heterogeneity in availability for photoidentification, as well as differences between individuals in the distinctiveness of their markings, but there are effective methods for dealing with these issues (Whitehead \& Wimmer 2005). A bigger challenge is the field work that would be required. Photoidentification is usually best accomplished from small vessels. Compared with the Scotian Shelf population, in the Baffin-Labrador area and northeast Atlantic population centres, the ani- mals are more widely distributed in cold, offshore waters where the weather is often poor.

This is a promising species for acoustic surveying as the animals spend much of their time making regular and distinctive echolocation clicks (Hooker \& Whitehead 2002, Barlow et al. 2005, Wahlberg et al. 2011). However, towed hydrophone surveys would also need to consider ship-seeking behaviour, and fixed hydrophones might therefore suffer fewer biases.

\section{Are central populations healthy and geographically peripheral ones in peril?}

While good abundance estimates are lacking, except for the Scotian Shelf population, the information that we have summarized suggests that the most easterly and westerly whaling areas currently contain few whales, whereas in the more central regions bottlenose whales are sighted reasonably regularly. This does not fit with what we know of current anthropogenic disturbance; for instance, seismic surveys are common near Svalbard, where the whales seem to be fairly common, but rare off Andenes, where the whales are rare. Subpopulations in the geographically central parts of a species range are usually assumed to be more resilient than those at its periphery (e.g. Baguette 2004), due to more optimal environmental variables near the centre of the range. However, the eastern and western extents of the northern bottlenose range seem constrained by continental shelves rather than increasing deviations of environmental variables from species optima, so it is not immediately clear why this paradigm should apply to the bottlenose whales. However, the apparently preferred water depth range for this species ( 800 to $1800 \mathrm{~m}$ ) is much more common in the central northern North Atlantic than off the continental shelves (Fig. 1). A larger area of preferred habitat may give more resilience to the whales off Iceland, the Faeroes and east Greenland. Although habitat models have been built for the Scotian Shelf (Hooker et al. 1999), and eastern Canada in general (Compton 2005), similar work should be carried out for the northeast Atlantic and used to examine this habitatextent-predicts-resilience hypothesis.

\section{What are the effects of current stressors on the species?}

The effects of past whaling on the northern bottlenose are uncertain, and so are the impacts of current 
human activities. Perhaps the most pressing of these are the interactions with fisheries in the LabradorBaffin area. There are reports that these interactions are extensive, but it is unclear what the effect is upon the whales, in terms of entanglement or other secondary anthropogenic effects, as well as upon the fishery in terms of depredation of bait or catch (COSEWIC 2011). Clearly, more independent observer data are needed for these fisheries, and if this could be coupled with photoidentification then we could learn something of the whale population in this remote area.

A second current anthropogenic threat to northern bottlenose whales is noise. We need both short-term (behavioural) and long-term (population level) studies of the changes, or lack of them, elicited by anthropogenic noise. In recent years, sophisticated processing of acoustic recordings from tags has started to provide detailed records of the short-term responses of cetaceans to noise (Aguilar Soto et al. 2006). Understanding the long-term effects of noise is much more challenging (Weilgart 2007); a prerequisite is detailed population monitoring.

\section{CONCLUSIONS}

The status of the northern bottlenose whale is uncertain in many respects. We do not know how the population is structured, what the effects of 2 phases of intense whaling were, how many animals there are today, or what the effects of current anthropogenic stressors are. In some respects, such as the lack of sightings in major whaling grounds off mainland Norway and Labrador, the picture that we have is disturbing. The northern bottlenose whale is an unusual species, even by cetacean standards, and some of its characteristics complicate efforts to assess its status. However, its inquisitiveness makes photoidentification and genetic sampling more efficient than in other beaked whale species, and its vocal behaviour allows effective passive acoustic monitoring, for instance using 'pop-up' hydrophones (Moors 2012). Collaborative photoidentification and genetic field research across the North Atlantic have led to a fairly clear assessment of the status of humpback whales (e.g. Smith et al. 1999). We suggest assessing the potential of a similar effort for the northern bottlenose.

Acknowledgements. We are grateful to Randall Reeves for pointing us to information on the current Greenland hunt, to Emer Rogan for Irish stranding data, and to Rob Deaville and Brian Smith for UK stranding data. The paper was improved as a result of useful comments by reviewers.

\section{LITERATURE CITED}

Aguilar Soto N, Johnson M, Madsen PT, Tyack PL, Bocconcelli A, Borsani FJ (2006) Does intense ship noise disrupt foraging in deep-diving Cuvier's beaked whales (Ziphius cavirostris)? Mar Mamm Sci 22:690-699

Baguette M (2004) The classical metapopulation theory and the real, natural world: a critical appraisal. Basic Appl Ecol 5:213-224

Barlow J, Ferguson MC, Perrin WF, Ballance L and others (2005) Abundance and densities of beaked and bottlenose whales (family Ziphiidae). J Cetacean Res Manag 7: 263-270

Benjaminsen $\mathrm{T}$ (1972) On the biology of the bottlenose whale, Hyperoodon ampullatus (Forster). Norw J Zool 20:233-241

Benjaminsen T, Christensen I (1979) The natural history of the bottlenose whale, Hyperoodon ampullatus (Forster). In: Winn HE, Olla BL (eds) Behavior of marine animals. Plenum, New York, NY, p 143-164

Bjørke H (2001) Predators of the squid Gonatus fabricii (Lichtenstein) in the Norwegian Sea. Fish Res 52: 113-120

Bloch D, Desportes G, Zachariassen M, Christensen I (1996) The northern bottlenose whale in the Faroe Islands, 1584-1993. J Zool 239:123-140

Cañadas A, Macleod K, Mikkelsen B, Rogan E and others (2011) Abundance and distribution of beaked whales in the European Atlantic. Paper presented to the IWC Scientific Committee, May 2011 SC/63/SM13. IWC, Cambridge

Christensen I (1973) Age determination, age distribution and growth of bottlenose whales, Hyperoodon ampullatus (Forster), in the Labrador Sea. Norweg J Zool 21: 331-340

Christensen I (1975) Preliminary report on the Norwegian fishery for small whales: expansion of Norwegian whaling to arctic and northwest Atlantic waters, and Norwegian investigations of the biology of small whales. J Fish Res Board Can 32:1083-1094

Christensen I (1993) The North Atlantic bottlenose whale (Hyperoodon ampullatus). NAMMCO Working Group on Killer and Northern Bottlenose Whales, Reykjavik 24-25 Nov 1993 SC-WG/NBK 1/5. NAMMCO, Tromsø

Christensen I, Ugland KI (1983) The history of exploitation and status of the northeast Atlantic bottlenose whale (Hyperoodon ampullatus). Paper presented to the IWC Scientific Committee, June 1983 SC/35/SM15. IWC, Cambridge

Christensen I, Jonsgård Å, Rorvik CJ (1977) Some notes concerning the bottlenose fishery in the North Atlantic after the Second World War, with particular reference to the westward expansion. Rep Int Whal Comm 27:226-227

Clapham PJ, Young SB, Brownell RL (1999) Baleen whales: conservation issues and the status of the most endangered populations. Mammal Rev 29:37-62

Clarke R (1981) Whales and dolphins of the Azores and their exploitation. Rep Int Whal Comm 31:607-615

Compton R (2005) Predicting key habitat and potential distribution of northern bottlenose whales (Hyperoodon ampullatus) in the Northwest Atlantic Ocean. MSc dissertation, University of Plymouth, Plymouth

Cooke JG (1985) On the relationship between catch per unit effort and whale abundance. Rep Int Whal Comm 35: $511-519$ 
COSEWIC (Committee on the Status of Endangered Wildlife in Canada) (2011) COSEWIC assessment and status report on the northern bottlenose whale Hyperoodon ampullatus in Canada. COSEWIC, Ottawa

Cox TM, Ragen TJ, Read AJ, Vos E and others (2006) Understanding the impacts of anthropogenic sound on beaked whales. J Cetacean Res Manag 7:177-187

> Dalebout ML, Ruzzante DE, Whitehead H, Øien NI (2006) Nuclear and mitochondrial markers reveal distinctiveness of a small population of bottlenose whales (Hyperoodon ampullatus) in the western North Atlantic. Mol Ecol 15:3115-3129

Department of Fisheries and Oceans (2009) Recovery strategy for the Northern Bottlenose Whale, Scotian Shelf population, in Atlantic Canadian waters [Proposed]. Fisheries and Oceans Canada, Ottawa

Dufault S, Whitehead H, Dillon M (1999) An examination of the current knowledge on the stock structure of sperm whales (Physeter macrocephalus) worldwide. J Cetacean Res Manag 1:1-10

Fraser FC (1953) Report on Cetacea stranded on the British coasts from 1938 to 1947. British Museum of Natural History, No. 11, London

Gosselin JF, Lawson J (2005) Distribution and abundance indices of marine mammals in the Gully and two adjacent canyons of the Scotian Shelf before and during nearby hydrocarbon seismic exploration programs in April and July, 2003. In: Lee K, Bain H, Hurley GV (eds) Acoustic monitoring and marine mammal surveys in the Gully and outer Scotian Shelf before and during active seismic programs. Environmental Studies Research Funds Report No. 151. Fisheries and Oceans Canada, Dartmouth, NS, p 117-138

Gowans S, Whitehead H, Arch JK, Hooker SK (2000) Population size and residency patterns of northern bottlenose whales (Hyperoodon ampullatus) using the Gully, Nova Scotia. J Cetacean Res Manag 2:201-210

Gowans S, Whitehead H, Hooker SK (2001) Social organization in northern bottlenose whales (Hyperoodon ampullatus): not driven by deep water foraging? Anim Behav 62:369-377

Gray D (1882) Notes on the characters and habits of the bottlenose whale (Hyperoodon rostratus). Proc Zool Soc Lond 50:726-731

Gunnlaugsson T, Sigurjónsson J (1990) NASS-87: Estimation of whale abundance based on observations made onboard Icelandic and Faroese survey vessels. Rep Int Whal Comm 40:571-580

Harms U, Drescher HE, Huschenbeth E (1978) Further data on heavy metals and organochlorines in marine mammals from German coastal waters. Meeresforsch 26: 153-161

Herfst D (2004) Distribution of northern bottlenose whales, Hyperoodon ampullatus, along the coast of Labrador, Canada. Honours BSc dissertation, Dalhousie University, Halifax

Holt SJ (1977) Does the bottlenose whale necessarily have a sustainable yield, and if so is it worth taking? Rep Int Whal Comm 27:206-208

> Hooker SK, Baird RW (1999) Deep-diving behaviour of the northern bottlenose whale, Hyperoodon ampullatus (Cetacea: Ziphiidae). Proc Biol Sci 266:671-676

> Hooker SK, Whitehead H (2002) Click characteristics of northern bottlenose whales (Hyperoodon ampullatus). Mar Mamm Sci 18:69-80
Hooker SK, Whitehead H, Gowans S (1999) Marine protected area design and the spatial and temporal distribution of cetaceans in a submarine canyon. Conserv Biol $13: 592-602$

> Hooker SK, Iverson SJ, Ostrom P, Smith SC (2001) Diet of northern bottlenose whales as inferred from fatty acid and stable isotope analyses of biopsy samples. Can J Zool 79:1442-1454

Hooker SK, Whitehead H, Gowans S, Baird RW (2002) Fluctuations in distribution and patterns of individual range use of northern bottlenose whales. Mar Ecol Prog Ser 225:287-297

Hooker SK, Metcalfe TL, Metcalfe CD, Angell CM, Wilson JY, Moore MJ, Whitehead H (2008) Changes in persistent contaminant concentration and CYP1A1 protein expression in biopsy samples from northern bottlenose whales, Hyperoodon ampullatus, following the onset of nearby oil and gas development. Environ Pollut 152: 205-216

> Hooker SK, Baird RW, Fahlman A (2009) Could beaked whales get the bends? Effect of diving behaviour and physiology on modelled gas exchange for three species: Ziphius cavirostris, Mesoplodon densirostris and Hyperoodon ampullatus. Respir Physiol Neurobiol 167:235-246

> Houser DS, Howard R, Ridgway S (2001) Can divinginduced tissue nitrogen supersaturation increase the chance of acoustically driven bubble growth in marine mammals? J Theor Biol 213:183-195

International Whaling Commission (1977a) Report of the Scientific Committee. Rep Int Whal Comm 27:36-70

International Whaling Commission (1977b) Report of the Working Group on North Atlantic Whales, Oslo, April 1976. Rep Int Whal Comm 27:369-387

International Whaling Commission (2012) Report of the Scientific Committee. Annex L. Report of the SubCommittee on Small Cetaceans. J Cetacean Res Manag 13(Suppl):263-291

Jonsgård Å (1977) A note on the value of bottlenose whales in relation to minke whales and the influence of the market situation and the prices on Norwegian whaling activity. Rep Int Whal Comm 27:502-504

Kiszka J, Macleod K, Van Canneyt O, Walker D, Ridoux V (2007) Distribution, encounter rates, and habitat characteristics of toothed cetaceans in the Bay of Biscay and adjacent waters from platform-of-opportunity data. ICES J Mar Sci 64:1033-1043

Lawson JW, Gosselin JF (2009) Distribution and preliminary abundance estimates for cetaceans seen during Canada's marine megafauna survey - a component of the 2007 TNASS. Canadian Science Advisory Secretariat Research Document 2009/031, Ottawa

MacDonald RA (2005) Distribution and fisheries interactions of northern bottlenose whales (Hyperoodon ampullatus) in Davis Strait/Baffin Bay. BSc Honours dissertation, Dalhousie University, Halifax

> MacLeod CD (2009) Global climate change, range changes and potential implications for the conservation of marine cetaceans: a review and synthesis. Endang Species Res 7:125-136

MacLeod CD, Pierce GJ, Santos MB (2004) Geographic and temporal variations in strandings of beaked whales (Ziphiidae) on the coasts of the UK and the Republic of Ireland from 1800-2002. J Cetacean Res Manag 6:79-86

MacLeod CD, Perrin WF, Pitman R, Barlow J and others (2005) Known and inferred distributions of beaked whale 
species (Cetacea: Ziphiidae). J Cetacean Res Manag 7: 271-286

Mate B, Mesecar R, Lagerquist B (2007) The evolution of satellite-monitored radio tags for large whales: one laboratory's experience. Deep-Sea Res II 54:224-247

McDonald MA, Mesnick SL, Hildebrand JA (2006) Biogeographic characterization of blue whale song worldwide: Using song to identify population. J Cetacean Res Manag 8:55-65

McQuinn IH, Carrier D (2005) Far-field measurements of seismic airgun array pulses in the Nova Scotia Gully Marine Protected Area. In: Lee K, Bain H, Hurley GV (eds) Acoustic monitoring and marine mammal surveys in the Gully and outer Scotian Shelf before and during active seismic programs. Environmental Studies Research Funds Report No. 151. Department of Fisheries and Oceans, Dartmouth, NS, p 57-74

Mead JG (1989) Bottlenose whales Hyperoodon ampullatus (Forster, 1770) and Hyperoodon planifrons Flower, 1882. In: Ridgway SH, Harrison R (eds) Handbook of marine mammals. Academic Press, London, p 321-348

Miller PJO, Johnson MP, Madsen PT, Biassoni N, Quero M, Tyack PL (2009) Using at-sea experiments to study the effects of airguns on the foraging behavior of sperm whales in the Gulf of Mexico. Deep-Sea Res I 56:1168-1181

Mitchell E (1977) Evidence that the northern bottlenose whale is depleted. Rep Int Whal Comm 27:195-203

Moors HB (2012) Acoustic monitoring of Scotian Shelf northern bottlenose whales (Hyperoodon ampullatus). PhD dissertation, Dalhousie University, Halifax

NAMMCO (North Atlantic Marine Mammal Commission) (1993) Report of the scientific committee working group on northern bottlenose and killer whales. NAMMCO, Tromsø

NAMMCO (1995) Annual report 1995. NAMMCO, Tromsø

NAMMCO (2009) Annual report 2007-2008. NAMMCO, Tromsø

NAMMCO (2012) Annual report 2011. NAMMCO, Tromsø

Nowacek DP, Thorne LH, Johnston DW, Tyack PL (2007) Responses of cetaceans to anthropogenic noise. Mammal Rev 37:81-115

Oien N, Hartvedt S (2011) Northern bottlenose whales Hyperoodon ampullatus in Norwegian and adjacent waters. Paper presented to the IWC Scientific Committee, May 2011 SC/63/SM1. IWC, Cambridge

Olesiuk P, Bigg MA, Ellis GM (1990) Life history and population dynamics of resident killer whales (Orcinus orca) in the coastal waters of British Columbia and Washington State. Rep Int Whal Comm 12(Spec Issue):209-243

Pike DG, Gunnlaugsson T, Víkingsson GA, Desportes G, Mikkelson B (2003) Surface abundance of northern bottlenose whales (Hyperoodon ampulatus) from NASS1995 and 2001 shipboard surveys. NAMMCO/SC/11/ AE/11, Tromsø

Reeves RR, Mitchell E, Whitehead H (1993) Status of the northern bottlenose whale, Hyperoodon ampullatus. Can

Editorial responsibility: Jaume Forcada,

Cambridge, UK
Field Nat 107:490-508

Rogan E, Hernandez-Milian G (2011) Preliminary analysis of beaked whale strandings in Ireland: 1800-2009. Paper presented to the IWC Scientific Committee, May 2011 SC/63/SM19. IWC, Cambridge

Silva MA, Prieto R, Magalhães S, Cabecinhas R, Cruz A, Gonçalves J, Santos R (2003) Occurrence and distribution of cetaceans in the waters around the Azores (Portugal), summer and autumn 1999-2000. Aquat Mamm 29: 77-83

Simmonds MP, Lopez-Jurado LF (1991) Whales and the military. Nature 351:448

Smith TD, Allen J, Clapham PJ, Hammond PS and others (1999) An ocean-basin-wide mark-recapture study of the North Atlantic humpback whale (Megaptera novaeangliae). Mar Mamm Sci 15:1-32

Stone CJ (2003) The effects of seismic activity on marine mammals in UK waters, 1998-2000. JNCC Report No. 323. Joint Nature Conservation Committee, Peterborough

Thompson D (1928) On whales landed at the Scottish whaling stations during the years 1908-1914 and 1920-1927. Sci Invest Fish Board Scot 3:3-39

Víkingsson GA, Ólafsdóttir D, Gunnlaugsson T (2009) Iceland. Progress report on cetacean research, May 2008 to April 2009, with statistical data for the calendar year 2008. Report to Scientific Committee of International Whaling Commission. IWC 2009 SC/60/Prog.Rep.Iceland, IWC, Cambridge

Wahlberg M, Deedholm K, Heerfordt A, Møhl B (2011) Characteristics of biosonar signals from the northern bottlenose whale, Hyperoodon ampullatus. J Acoust Soc Am 130:3077-3084

> Weilgart LS (2007) The impacts of anthropogenic noise on cetaceans and implications for management. Can J Zool 85:1091-1116

Whitehead H (2002) Estimates of the current global population size and historical trajectory for sperm whales. Mar Ecol Prog Ser 242:295-304

Whitehead H, Wimmer $\mathrm{T}$ (2005) Heterogeneity and the mark-recapture assessment of the Scotian Shelf population of northern bottlenose whales (Hyperoodon ampullatus). Can J Fish Aquat Sci 62:2573-2585

Whitehead H, Faucher A, Gowans S, McCarrey S (1997a) Status of the northern bottlenose whale, Hyperoodon ampullatus, in the Gully, Nova Scotia. Can Field Nat 111: $287-292$

Whitehead H, Gowans S, Faucher A, McCarrey SW (1997b) Population analysis of northern bottlenose whales in the Gully, Nova Scotia. Mar Mamm Sci 13:173-185

> Whitehead H, MacLeod CD, Rodhouse P (2003) Differences in niche breadth among some teuthivorous mesopelagic marine mammals. Mar Mamm Sci 19:400-406

> Wimmer T, Whitehead H (2004) Movements and distribution of northern bottlenose whales, Hyperoodon ampullatus, on the Scotian slope and in adjacent waters. Can J Zool 82:1782-1794

Submitted: May 10, 2012; Accepted: August 28, 2012

Proofs received from author(s): October 24, 2012 